\section{A ripping roller coaster ride}

David J. Blacker, MD; and Eelco F.M. Wijdicks, MD

A 41-year-old woman presented with a right frontotemporal headache and drooping of the right eye. The previous day she rode a violent roller coaster ride twice (figure, left panel) and recalled vigorous jerking of her neck. Examination revealed a right Horner syndrome (figure, middle panel) with ptosis, meiosis, and no anhidrosis. Magnetic resonance angiography (figure, right panel) confirmed the diagnosis of right internal carotid artery dissection.

Several other cases of carotid dissection have been reported related to amusement park equipment. ${ }^{1}$ Roller coaster rides can generate force in excess of 4 "Gs," which in combination with neck movements could potentially rip the carotid intima. Distension of the injured arterial wall compresses the adjacent sympathetic fibers, ${ }^{2}$ resulting in a Horner syndrome, which is typically without anhidrosis, in lesions above the bifurcation, where the fibers supplying the face leave to traverse with the external carotid artery.

1. Braksiek R, Roberts D. Amusement park injuries and deaths. Ann Emerg Med 2002;39:65-72.

2. Mokri B, Sundt T, Houser W, Piepgras D. Spontaneous dissection of the cervical internal carotid artery. Ann Neurol 1986;19:126-138.

From the Department of Neurology, Mayo Clinic, Rochester, MN.

Received May 27, 2003. Accepted in final form July 18, 2003.

Address correspondence and reprint requests to Dr. Eelco F.M. Wijdicks, Mayo Clinic, 200 First Street SW, W8B, Rochester, MN 55905; e-mail: Wijde@mayo.edu
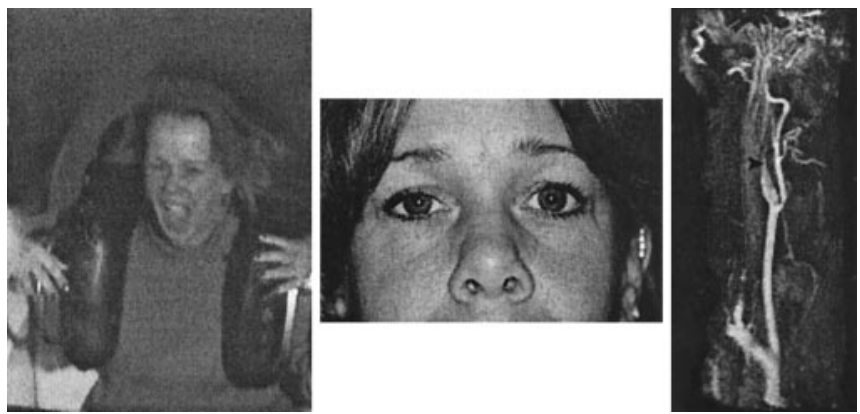

Figure. (A) The patient on the roller coaster ride. (B) Right Horner syndrome. (C) Magnetic resonance angiography confirmed the diagnosis of right internal carotid artery dissection. 


\title{
Neurology
}

\author{
A ripping roller coaster ride \\ David J. Blacker and Eelco F.M. Wijdicks \\ Neurology 2003;61;1255 \\ DOI 10.1212/01.WNL.0000092013.31543.47
}

This information is current as of November 10, 2003

\section{Updated Information \& Services}

\section{References}

Citations

Subspecialty Collections

Permissions \& Licensing

Reprints including high resolution figures, can be found at: http://n.neurology.org/content/61/9/1255.full

This article cites 2 articles, 0 of which you can access for free at: http://n.neurology.org/content/61/9/1255.full\#ref-list-1

This article has been cited by 4 HighWire-hosted articles: http://n.neurology.org/content/61/9/1255.full\#\#otherarticles

This article, along with others on similar topics, appears in the following collection(s):

\section{All Cerebrovascular disease/Stroke}

http://n.neurology.org/cgi/collection/all_cerebrovascular_disease_strok e

\section{All Imaging}

http://n.neurology.org/cgi/collection/all_imaging

Carotid artery dissection

http://n.neurology.org/cgi/collection/carotid_artery_dissection

MRI

http://n.neurology.org/cgi/collection/mri

Information about reproducing this article in parts (figures,tables) or in its entirety can be found online at:

http://www.neurology.org/about/about_the_journal\#permissions

Information about ordering reprints can be found online:

http://n.neurology.org/subscribers/advertise

Neurology ${ }^{\circledR}$ is the official journal of the American Academy of Neurology. Published continuously since 1951, it is now a weekly with 48 issues per year. Copyright. All rights reserved. Print ISSN: 0028-3878. Online ISSN: 1526-632X.

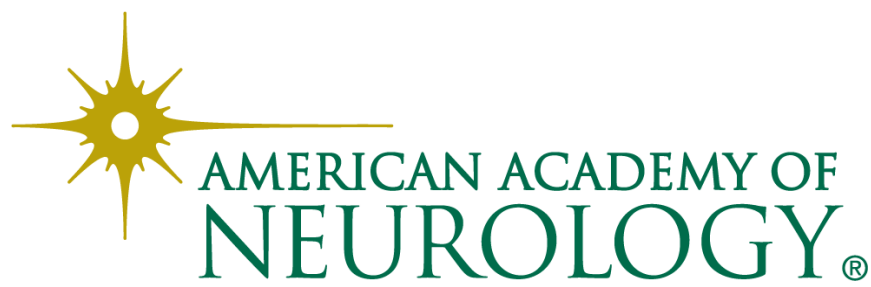

